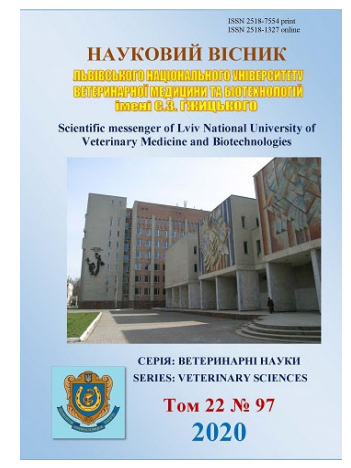

\author{
Науковий вісник Дьвівського національного університету \\ ветеринарної медицини та біотехнологій імені С.З. Гжицького. \\ Серія: Ветеринарні науки
}

Scientific Messenger of Lviv National University

of Veterinary Medicine and Biotechnologies.

Series: Veterinary sciences

\title{
Veterinary and sanitary evaluation of sausage products in Zhytomyr according to quality and safety indicators
}

\author{
V. A. Kotelevych, K. S. Larina \\ Zhytomyr National Agroecological University, Zhytomyr, Ukraine
}

Article info

Received 10.02.2020

Received in revised form 09.03 .2020

Accepted 10.03.2020

Zhytomyr National Agroecological University, Korolova Str., 39, Zhytomyr, 10025, Ukraine. Tel.:+38-067-456-23-80 E-mail:valya.kotelevich@ukr.net
Kotelevych, V. A., \& Larina, K. S. (2020). Veterinary and sanitary evaluation of sausage products in Zhytomyr according to quality and safety indicators. Scientific Messenger of Lviv National University of Veterinary Medicine and Biotechnologies. Series: Veterinary sciences, 22(97), 112 117. doi: $10.32718 /$ nvlvet9718

Considering the issue of proper veterinary and sanitary control over the production of sausage products, identification of their quality and safety criteria is extremely important. The aim of our research was to carry out a comparative analysis of the quality and safety of sausage products "Miasna Hyldia" of Ltd Zhytomyr Meat Processing Plant i VTF "Marian" Ltd, which is implemented in the trade network of Zhytomyr. The research and production experiment was carried out in the conditions of the sanitary-hygienic laboratory and bacteriological laboratory of the State Institution "Zhytomyr Regional Laboratory Center of the Ministry of Health of Ukraine". Samples of sausages (6 samples of each species) were taken directly from the trading kiosks of Zhytomyr in the autumn season. According to organoleptic studies, the sausages boiled and smoked by both producers had a dry, durable, elastic shell, mold, and no mildew; the consistency of the section was dense both at the periphery and in the center; noted pink, uniform coloring of minced meat on the cut, white pork. Samples of cooked sausages were made by both manufacturers: there was no dry, elastic shell without damage, mucus and mold; minced sausage slices were evenly colored, white pork. The texture of the sausages was elastic, the taste of the sausages and wipes was juicy, with the inherent taste and aroma of these products, without the foreign smell and taste, moderately salty. According to the results of bacteriological studies, which were carried out in accordance with the requirements of regulatory documents, bacteria of the group of Escherichia coli were detected in the samples of sausages "Shynkova" and "Sardelky with cheese" manufactured by Ltd VTF Marian. In the samples of "Shynkova" sausage "Miasna Hildiya" Ltd "Zhytomyr Meat Processing Plant" the salt content was $2.6 \%$ at the rate of $2.5 \%$. According to the regulatory requirements, the permissible content of sodium nitrite is up to $0.005 \%$, and in the samples of the "Miasna Hildiya" sausage "Molochna", the Zhytomyr meat processing plant Ltd, this indicator reached $0.0082 \%$. To increase the safety of sausages, we propose to use a natural dye by the method of Kovbasenko V. M., Gorobeya O. M. (2001), which is made from the blood of slaughter animals by stabilizing its 2-3\% table salt and treatment with $6 \%$ or $9 \%$ alcohol solution of acetic acid and gives the sausages a stable color. To eliminate the risk of hazards in the production of sausages, it is necessary to apply an effective system of quality control and safety according to the HACCP system using critical points of veterinary and sanitary control from procurement of raw materials to processing into meat products, storage, transportation and sale.

Key words: sausages, organoleptic, physicochemical, bacteriological indicators, veterinary and sanitary assessment.

\section{Ветеринарно-санітарна оцінка ковбасних виробів у місті Житомир за показниками якості та безпечності}

\author{
В. А. Котелевич, К. С. Ларіна
}

Житомирський начіональний агроекологічний університет, м. Житомир, Украӥна 
Беручи до уваги, щуо питання належного ветеринарно-санітарного контролю за виробництва ковбасних виробів, ідентифікаціі їх критерії якості й безпеки є надзвичайно актуальним, метою наших досліджень було провести порівняльний аналіз якості $i$ безпечності ковбасних виробів “М'ясна гільдія” ТОВ Житомирський м'ясокомбінат і ТОВ ВТФ “Мар'ян”, ияо реалізуються в торгівельній мережі м. Житомир. Науково-виробничий дослід проводили в умовах санітарно-гігієнічної лабораторії та бактеріологічної лабораторії ДУ “Житомирський обласний лабораторний иентр МОЗ України”. Зразки ковбас (по 6 проб кожного виду) відбирали безпосередньо в торгівельних кіосках м. Житомира в осінню пору року За органолептичними дослідженнями ковбаси варено-копчені обох виробників мали суху, міџну, еластичну оболонку, нальотів плісняви не було виявлено, оболонка щільно прилягала до фаршу; консистенція на розрізі була щчільною як по периферії, так $і$ в иентрі; відмічали рожеве, рівномірне забарвлення фариу на розрізі, шпик білий. Зразки варених ковбас та сосисок і сардельок обох виробників мали: суху, еластичну оболонку без пошкоджень, слизу та плісняви не було; фари на розрізі батонів ковбас був рівномірно забарвлений, шпик білий. Консистенція сосисок була пружньою, на смак сосиски і сардельки були соковиті, з властивим данним виробам смаком $і$ запахом, без стороннього запаху та присмаку, помірно солоні. За результатами бактеріологічних досліджень, які проводили у відповідності з вимогами нормативних документів, у зразках ковбаси “Шинкова” та “Сардельки з сиром” ТОВ ВТФ “Мар'ян” було виявлено бактерї групи кишкової палички. У зразках ковбаси “Шинкова” “М'ясна гільдія”ТОВ “Житомирський м'ясокомбінат” вміст солі становив 2,6\% при нормі 2,5\%. За нормативними вимогами допустимий вміст нітриту натрію до 0,005 \%, а у зразках ковбаси “Молочна” “М'ясна гільдія” ТОВ Житомирський м'ясокомбінат ией показник сягав 0,0082%. Для підвищення безпечності ковбасних виробів пропонуємо застосовувати природній барвник за методом Ковбасенко В. М., Горобея О. М. (2001), який виготовляється із крові забійних тварин иляхом стабілізації ї̈ 2-3\% кухонної солі і обробки 6 \% або 9 \% спиртовим розчином оцтової кислоти і надає ковбасам стійкого стабільного кольору. Для усунення ризику небезпек при виробництві ковбасних виробів необхідно застосовувати дієву систему контролю за якістю та безпечністю за системою НАССР з використанням критичних точок ветеринарносанітарного контролю від заготівлі сировини до переробки у м'ясопродукти, зберігання, транспортування та реалізації.

Ключові слова: ковбасні вироби, органолептичні, фізико-хімічні, бактеріологічні нпоказники, ветеринарно-санітана оцінка.

\section{Вступ}

Глобалізація ринку харчової продукції останнім часом призвела до необхідності вирішувати проблему якості та безпечності продуктів харчування й зменшення ризиків їхнього негативного впливу на здоров'я населення. Отже, одним з найважливіших і пріорітетних завдань держави $є$ вирішення продовольльчої безпеки країни, а саме: забезпечення належної якості та безпечності харчових продуктів. На сьогодні в усьому світі стали суттєво жорстокішими вимоги, що висуваються споживачем до якості продукції. У сучасних умовах жорсткої конкурентної боротьби за ринки збуту продукції підприємства розвинутих країн все ширше застосовують ефективний інструмент забезпечення успіху - системи якості, які відповідають визнаним, що містяться у Міжнародних та Європейських стандартах 3 якості та сертифікації (Kovbasenko \& Horobei, 2001; Kasianchuk et al., 2015; Kotelevich, 2017). М'ясопродукти виготовляють на величезній кількості м'ясопереробних підприємств різної потужності та суб'єктами індивідуального підприємництва, що призвело до зниження їх санітарної якості та безпеки щодо споживача. Особливо це відноситься до м'ясопродуктів, що виготовляються на малотонажних підприємствах і суб'єктами індивідуального підприємництва, де державний ветеринарно-санітарний контроль майже відсутній (Khitska et al., 2008; Bohatko et al., 2011; 2016). Крім цього, виробництвом м'ясопродуктів часто займаються люди, які не мають професійної підготовки. Тому в торгівельну мережу, особливо на ринки, потрапляє багато продукції низької санітарної якості, фальсифікованої та ін., яка може бути джерелом харчових токсикоінфекцій, токсикозів та інших захворювань у людей (Bohatko et al., 2013; Kotelevych et al., 2015; 2017). Викликає занепокоєння також те, що при виробництві м'ясопродуктів використовуються нітрити - високотоксичні сполуки. Проблема виготовлення м'ясопродуктів за безнітрит- ною технологією не нова. Над нею працювало ряд дослідників, але досі вона не вирішена повністю (Kovbasenko \& Horobei, 2001). Проблема заміни нітриту натрію на барвник ускладнюється багатофункціональної роллю солей азотистої кислоти під час виробництва ковбас. Нітрит натрію, крім фіксації кольору, специфічно впливає на окиснювальну мікробіологічну стабільність, смак і запах м'ясопродуктів. У зв'язку 3 інгібуючою дією нітритів на ріст мікроорганізмів виникла неможливість повністю відмовитися від їх використання в технології варених ковбас. Однак дослідженнями Колесник Т. Л., Колесник А. О. (Kolesnyk \& Kolesnyk, 2015) встановлено, що рівень заміни нітриту натрію барвником із крові забійних тварин, що дозволяє отримати варені ковбаси, які відповідають санітарним вимогам за бактеріологічними показниками становить: за вмісту в варених ковбаcax $2 \%$ барвника і 1,5 мг\% нітриту натрію (мікробне число в готових виробах не перевищувало $10^{3}$ протягом 4 діб зберігання за відсутності спорових анаеробних бактерій, протея, сальмонел, БГКП і коагулазопозитивного стафілокока). Автори наголошують, що додавання в рецептуру ковбас “Любительська" вищого сорту, “Молочна” вищого сорту, “Південна" першого сорту, "Московська" першого сорту барвника 3 крові забійних тварин дозволяє знизити вміст нітритів у $3,5-4,6$ разів.

Ковбаси є важливим продуктом харчування, основною сировиною яких $\epsilon$ продукти забою тварин: яловичина і свинина, зрідка - баранина, конина та ін. Сировина має вирішальне значення при виробництві ковбас (Khitska et al., 2008; Kotelevych et al., 2015). Ковбасні вироби - це готовий високопоживний м'ясний продукт із специфічним смаком та ароматом. Доброякісні ковбаси, виготовлені в належних санітарно-гігієнічних умовах з м'яса здорових тварин, майже не містять мікроорганізмів. Ковбаси, виготовлені 3 несвіжої сировини і м'яса хворих тварин, навіть після варіння і копчення можуть містити спорові та вегета- 
тивні форми мікроорганізмів. Такі ковбаси швидко псуються, особливо в літню пору року. Поверхня їх робиться матовою, липкою, покривається плісенню (Bohatko et al., 2011). Харчова безпека і стійкість м'ясних виробів при зберіганні - це важливі та необхідні умови як для споживачів, так і для виробників, вони залежать від багатьох факторів (особливостей основної та допоміжної сировини, санітарного та технічного стану обладнання, правильності проведення технологічних операцій, забезпечення необхідних режимів і т.д.). Як відомо, ковбасні вироби мають обмежений строк зберігання, який чітко регламентовано в нашій країні. Проблему подовження строків зберігання найчастіше вирішують за рахунок внесення консервуючих речовин хімічної природи (Trokhymenko et al., 2018). Проте, поставлена проблема має ще один варіант рішення - мікробіологічний, який полягає у використанні стартових культур. Як зазначають Калнаус К. О., Хицька О. А., в останні роки за врахування сучасних вимог нутріціології та економічної ситуації виробники частіше надають перевагу виробництву ковбас за власними технічними умовами. Вони впроваджують у виробництво нові рецептури м'ясної продукції заданого хімічного складу, збалансованої за основними складовими компонентами, застосовують сучасні технології, які оптимізують і наближають до мінімуму нітрити під час переробки продукції тваринництва, забезпечують раціональне використання продуктів забою та різних харчових добавок. Тому питання належного ветеринарно-санітарного контролю за виробництва ковбасних виробів, ідентифікації їх критеріїв якості й безпеки є надзвичайно актуальним (Khitska et al., 2008; Bohatko et al., 2011; Kotelevych et al., 2015; Kotelevich, 2017).

Беручи до уваги вищезазначене, метою наших досліджень було провести порівняльний аналіз якості і безпечності ковбасних виробів двох виробників, що реалізуються в торгівельній мережі м. Житомира.

Для вирішення поставленної мети перед нами були поставленні такі завдання:

- провести органолептичні дослідження ковбасних виробів;

- провести бактеріологічні дослідження;

- визначити деякі фізико-хімічні показники;

- за результатами досліджень здійснити ветеринарно-санітарну оцінку та надати пропозиції виробництву.

\section{Матеріал і методи досліджень}

Науково-виробничий дослід проводили в умовах санітарно-гігієнічної лабораторії разом з лікаремлаборантом Хреновою Л. Г. та бактеріологічній лабораторії разом з лікарем Лисенко О. М. ДУ “Житомирський обласний лабораторний центр МО3 України”. Зразки ковбас (по 6 проб кожного виду) відбирали безпосередньо в торгівельних кіосках м. Житомира в осінню пору року. Матеріалом для досліджень були: ковбаса "Лікарська", “Молочна", “Шинкова" та "Сардельки з сиром” і сосиски “Молочні” двох виробни- ків: “М'ясна гільдія” ТОВ Житомирський м'ясокомбінат і ТОВ ВТФ “Мар'ян”. Бактеріологічні дослідження проводили за ДСТУ 4436: 2005 “Ковбаси варені, сосиски, сардельки, хліби м'ясні. Загальні технічні умови". Методи мікробіологічного аналізу відповідали ГОСТ 9958-81 “Изделия колбасные и продукты из мяса. Методы бактериологического анализа (с изменениями № 1, 2)", які включали висів досліджуваного матеріалу на живільні середовища, висів отриманих культур на диференціальні середовища 3 метою визначення їх морфологічних та біохімічних властивостей. Визначали загальну кількість мезофільних аеробних та факультативно анаеробних мікроорганізмів в 1 г (МАФАнМ), вміст бактерій групи кишкової палички в 1 г (БГКП), анаеробних спорових сульфітредукуючих бактерій (у 0,1 г) і сальмонел (у 25 г). На додаток до мікроорганізмів, що регламентуються за зазначеними вище вимогами, досліджено вміст у ковбасах протея (в 1 г) та золотистого коагулазопозитивного стафілокока (в 1 г).

Органолептичні та фізико-хімічні дослідження проводили у відповідності 3 вимогами ДСТУ 4436:2005 “Ковбаси варені, сосиски, сардельки, хліби м'ясні".

Визначення масової частки натрію хлориду проводили за методом Мора, масової частки нітриту натрію - фотоколориметраичним методом.

Отримані результати оброблені статистично за допомогою комп'ютерної програми MS Excel 2003, рівень вірогідності (Р) 3 використанням таблиці tкритеріїв Ст'юдента.

\section{Результати та їх обговорення}

Встановлено, що за безпечністю ковбасні вироби не завжди відповідають ветеринарно-санітарним вимогам і можуть бути джерелом харчових отруєнь. При проведенні органолептичних досліджень ковбасних виробів в осінній період ми спостерігали наступні показники: ковбаси варено-копчені обох виробників мали суху, міцну, еластичну оболонку, нальотів плісняви не було виявлено, оболонка щільно прилягала до фаршу; консистенція на розрізі була щільною як по периферії, так і в центрі; відмічали рожеве, рівномірне забарвлення фаршу на розрізі, сірі плями відсутні, шпик білий. Зразки варених ковбас та сосисок і сардельок обох виробників мали: суху, еластичну оболонку без пошкоджень, слизу та плісняви не було; фарш на розрізі батонів ковбас був рівномірно забарвлений, шпик білий. Консистенція сосисок була пружньою, на смак сосиски і сардельки були соковиті. Визначали соковитість в гарячому стані. Сосиски сардельки були 3 властивим данним виробам смаком і запахом, без стороннього запаху та присмаку, помірно солоні.

Проведеними бактеріологічними дослідженнями (табл. 1) в усіх зразках ковбасних виробів МАФАнМ була у межах допустимих нормативних вимог $(2,0 \pm 0,04) \times 10^{3}$ КУО в 1 г. Сульфітредукуючі спорові анаероби, коагулазопозитивний стафілокок, сальмонели і протей в досліджуваних зразках не було виявлено. 
Сальмонели, лістерії моноцитогенез, сульфітредукуючі клостридії та протей не було виявлено в жодному зразку. Однак, у зразках ковбаси "Шинкова" та “Сардельки з сиром” (ТОВ ВТФ “Мар'ян”) було виявлено бактерії групи кишкової палички (БГКП).
Висів червоно-рожевих колоній, що виросли на Ендо, на середовище Лактоза - газ з поплавком після термостатування показав утворення кислоти i газу, який збирається в поплавку. Це підтверджує наявність БГКП в досліджуваних зразках.

\section{Таблиця 1}

Бактерільне обсіменіння м'ясопродуктів двох виробників, що реалізувалися в торгівельній мережі м. Житомир $(\mathrm{M} \pm \mathrm{m}, \mathrm{n}=6, \mathrm{P} \leq 0,05)$

\begin{tabular}{|c|c|c|c|}
\hline М'ясопродукти & $\begin{array}{c}\text { Загальне бактеріальне } \\
\text { обсіменіння (МАФАнМ) }\end{array}$ & $\begin{array}{c}\text { Бактерії групи кишкової } \\
\text { палички (БГКП) }\end{array}$ & $\begin{array}{c}\text { Сальмонели та лістерія } \\
\text { моноцитогенез }\end{array}$ \\
\hline Ковбаса “Лікарська" & $(251+002) \times 10^{2}$ & в $1,0 \mathrm{~cm}^{3}$ & в $25,0 \mathrm{~cm}^{3}$ \\
\hline$(\mathrm{M})^{*}$ & $(2,51 \pm 0,02) \times 10^{2}$ & не виявлено & не виявлено \\
\hline Ковбаса "Молочна" & $02) \times 10^{2}$ & в $1,0 \mathrm{~cm}^{3}$ & в $25,0 \mathrm{~cm}^{3}$ \\
\hline$(\mathrm{M})^{*}$ & $0,02) \times 10^{2}$ & не виявлено & не виявлено \\
\hline Ковбаса "Шинкова" & $(3,21 \pm 0,04) \times 10^{2}$ & в $1,0 \mathrm{~cm}^{3}$ & в $25,0 \mathrm{~cm}^{3}$ \\
\hline 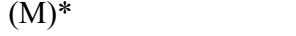 & & виявлено & не виявлено \\
\hline $\begin{array}{l}\text { "Сардельки з сиром” } \\
(\mathrm{M})^{*}\end{array}$ & $(2,8 \pm 0,03) \times 10^{2}$ & $\begin{array}{l}\text { в } 1,0 \mathrm{~cm}^{3} \\
\text { виявлено }\end{array}$ & $\begin{array}{c}\text { в } 25,0 \mathrm{~cm}^{3} \\
\text { не виявлено }\end{array}$ \\
\hline $\begin{array}{l}\text { Сосиски “Молочні”, } \\
\text { (М)* }\end{array}$ & $(3,1 \pm 0,02) \times 10^{2}$ & $\begin{array}{c}\text { в } 1,0 \mathrm{~cm}^{3} \\
\text { не виявлено }\end{array}$ & $\begin{array}{c}\text { в } 25,0 \mathrm{~cm}^{3} \\
\text { не виявлено }\end{array}$ \\
\hline $\begin{array}{l}\text { Ковбаса "Лікарська" } \\
(\text { ЖМ)** }\end{array}$ & $(9,0 \pm 0,04) \times 10^{1}$ & $\begin{array}{c}\text { в } 1,0 \mathrm{~cm}^{3} \\
\text { не виявлено }\end{array}$ & $\begin{array}{c}\text { в } 25,0 \mathrm{~cm}^{3} \\
\text { не виявлено }\end{array}$ \\
\hline $\begin{array}{l}\text { Ковбаса "Молочна" } \\
(Ж М)^{* *}\end{array}$ & $(1,1 \pm 0,02) \times 10^{2}$ & $\begin{array}{c}\text { в } 1,0 \mathrm{~cm}^{3} \\
\text { не виявлено }\end{array}$ & $\begin{array}{c}\text { в } 25,0 \mathrm{~cm}^{3} \\
\text { не виявлено }\end{array}$ \\
\hline $\begin{array}{l}\text { Ковбаса “Шинкова” } \\
(\text { М)** }\end{array}$ & $(8,0 \pm 0,03) \times 10^{1}$ & $\begin{array}{c}\text { в } 1,0 \mathrm{~cm}^{3} \\
\text { не виявлено }\end{array}$ & $\begin{array}{c}\text { в } 25,0 \mathrm{~cm}^{3} \\
\text { не виявлено }\end{array}$ \\
\hline “Сардельки з сиром” & Мікробне число & в $1,0 \mathrm{~cm}^{3}$ & в $25,0 \mathrm{~cm}^{3}$ \\
\hline$(Ж M) * *$ & $>10$ & не виявлено & не виявлено \\
\hline Сосиски “Молочні" & Мікробне число & в $1,0 \mathrm{~cm}^{3}$ & B $25,0 \mathrm{~cm}^{3}$ \\
\hline$(Ж \mathrm{M})^{* *}$ & $>10$ & не виявлено & не виявлено \\
\hline
\end{tabular}

Примітки: * - ТОВ ВТФ “Мар'ян” (Товариство з обмеженою відповідальністю Виробничо-торгова фірма "Мар'ян”); ** _ “Мясна гільдія” ТОВ “Житомирський м’ясокомбінат”.

Враховуючи біохімічні властивості виділених мікроорганізмів, вони відносяться до роду Citrobacter біохімічний варіант freundii. При фарбуванні мазка цих колоній за Грамом спостерігали дрібні грамнегативні палички. За результатами бактеріологічних досліджень ковбаса "Шинкова" та "Сардельки $з$ сиром” ТОВ ВТФ “Мар'ян” не відповідають нормативним вимогам і можуть бути джерелом харчових отру$\epsilon$ нн.

Вода, що входить до складу м'яса i м'ясопродуктів, зв'язується 3 їх компонентами та структурними утвореннями. Масова частка вологи у варених ковбасних виробах не лише збільшує масу виробу, а також прискорює процеси псування. Масова частка вологи у досліджених зразках ковбас, виготовлених в умовах "М'ясна гільдія” ТОВ “Житомирський м'ясокомбінат" і ТОВ ВТФ “Мар'ян”, коливалася в межах від 59,5 \% до 69,4 \%, що вказує на відсутність перевищення допустимих значень (70 \% і 72 \% відповідно вищого та 1 і 2 гатунку). За вмістом вологи, усі досліджуванні зразки ковбасних виробів відповідали нормативним вимогам (табл. 2).

Таблиця 2

Вміст вологи_в ковбасах, що реалізувались в торгівельній мережі м. Житомир ( $\mathrm{M} \pm \mathrm{m}, \mathrm{n}=6, \mathrm{P} \leq 0,05)$

\begin{tabular}{|c|c|c|}
\hline Виробник & М'ясопродукти & Масова частка вологи, \% \\
\hline & Ковбаса “Лікарська" & $59,9 \pm 0,5$ \\
\hline “М'ясна гільдія” & Ковбаса "Молочна" & $62,3 \pm 0,7$ \\
\hline ТОВ “Житомирський & Ковбаса "Шинкова" & $65,3 \pm 0,4$ \\
\hline м'ясокомбінат" & Сосиски “Молочні” & $62,5 \pm 0,2$ \\
\hline & “Сардельки з сиром” & $67,3 \pm 0,3$ \\
\hline \multirow{5}{*}{$\begin{array}{l}\text { ТОВ ВТФ } \\
\text { “Мар'ян” }\end{array}$} & Ковбаса “Лікарська" & $64,5 \pm 0,6$ \\
\hline & Ковбаса "Молочна" & $61,8 \pm 0,2$ \\
\hline & Ковбаса "Шинкова" & $69,4 \pm 0,4$ \\
\hline & Сосиски “Молочні” & $68,9 \pm 0,5$ \\
\hline & “Сардельки з сиром” & $59,5 \pm 0,3$ \\
\hline
\end{tabular}


За результатами досліджень щодо вмісту нітриту натрію виявлено порушення (табл. 3). За нормативними вимогами до $0,005 \%$ у зразках ковбаси "Молочна” “М'ясна гільдія" ТОВ Житомирський м’ясокомбінат цей показник сягав 0,0082 \%.
Результати щодо вмісту хлористого натрію в ковбасних виробах двох виробників наведено в таблиці 4.

Таблиця 3

Вміст нітриту натрію в ковбасах, що реалізувались в торгівельній мережі м. Житомира $(\mathrm{M} \pm \mathrm{m}, \mathrm{n}=6, \mathrm{P} \leq 0,05)$

\begin{tabular}{|c|c|c|}
\hline Виробник & М'ясопродукти & Масова частка нітриту, \% \\
\hline & ковбаса “Лікарська" & $0,0047 \pm 0,0002$ \\
\hline “М'ясна гільдія” & ковбаса “Молочна” & $0,0082 \pm 0,0003$ \\
\hline ТОВ “Житомирський & ковбаса “Шинкова” & $0,0019 \pm 0,0002$ \\
\hline м'ясокомбінат" & сосиски “Молочні” & $0,0011 \pm 0,0004$ \\
\hline & “Сардельки з сиром” & $0,0047 \pm 0,0001$ \\
\hline \multirow{5}{*}{$\begin{array}{l}\text { ТОВ ВТФ } \\
\text { "Мар'ян" }\end{array}$} & ковбаса “Лікарська” & $0,0015 \pm 0,0002$ \\
\hline & ковбаса "Молочна" & $0,0014 \pm 0,0003$ \\
\hline & ковбаса “Шинкова” & $0,0030 \pm 0,0002$ \\
\hline & сосиски “Молочні”" & $0,0012 \pm 0,0004$ \\
\hline & “Сардельки з сиром” & $0,0006 \pm 0,0002$ \\
\hline
\end{tabular}

\section{Таблиця 4}

Вміст хлористого натрію в ковбасних, що реалізувались в торгівельній мережі м. Житомира $(\mathrm{M} \pm \mathrm{m}, \mathrm{n}=6$, $\mathrm{P} \leq 0,05)$

\begin{tabular}{|c|c|c|}
\hline Виробник & М'ясопродукти & Масова частка хлористого натрію, \% \\
\hline & ковбаса “Лікарська" & $2,1 \pm 0,02$ \\
\hline “М’ясна гільдія” ТОВ & ковбаса “Молочна” & $2,1 \pm 0,01$ \\
\hline “Житомирський & ковбаса “Шинкова” & $2,6 \pm 0,03$ \\
\hline м'ясокомбінат" & сосиски “Молочні” & $1,9 \pm 0,03$ \\
\hline & “Сардельки з сиром” & $2,2 \pm 0,02$ \\
\hline \multirow{5}{*}{$\begin{array}{l}\text { ТОВ ВТФ } \\
\text { "Мар'ян" }\end{array}$} & ковбаса “Лікарська" & $2,4 \pm 0,01$ \\
\hline & ковбаса "Молочна" & $2,3 \pm 0,02$ \\
\hline & ковбаса “Шинкова” & $2,3 \pm 0,03$ \\
\hline & сосиски “Молочні” & $2,1 \pm 0,01$ \\
\hline & “Сардельки з сиром” & $1,9 \pm 0,01$ \\
\hline
\end{tabular}

Таким чином, за результатами фізико-хімічних досліджень за вмістом вологи усі досліджуванні зразки ковбасних виробів відповідали нормативним вимогам, а за вмістом солі і нітриту натрію не відповідали нормативним вимогам ковбасні вироби, що наведені в таблиці 5.

\section{Таблиця 5}

Результати фізико-хімічних досліджень ковбасних виробів $(\mathrm{M} \pm \mathrm{m}, \mathrm{n}=6, \mathrm{P} \leq 0,05)$

\begin{tabular}{|c|c|c|}
\hline Зразки ковбасних виробів & $\begin{array}{c}\text { Вміст солі } \\
\text { (норма } 2,5 \%)\end{array}$ & $\begin{array}{c}\text { Вміст нітриту натрію } \\
\text { (норма } 0,005 \%)\end{array}$ \\
\hline $\begin{array}{c}\text { “Шинкова” } \\
\text { "М'ясна гільдія” } \\
\text { тОВ “Житомирський м’ясокомбінат” }\end{array}$ & $2,6 \pm 0,03 \%$ & \\
\hline $\begin{array}{c}\text { "Молочна” } \\
\text { “М'ясна гільдія” } \\
\text { тОВ “Житомирський м’ясокомбінат” }\end{array}$ & & $0,0082 \pm 0,0003 \%$ \\
\hline
\end{tabular}

Підсумовуючи отриманні результати досліджень, необхідно зазначити, що обсіменіння мікрофлорою i токсичність м'ясопродуктів залежить від різних факторів. Основними факторами, що впливають на санітарну якість та безпеку м'ясопродуктів, які реалізуються в торгівельній мережі, є дотримання технології виробництва, санітарний стан м'ясопереробного підприємства та місць реалізації, умов транспортування і дотримання особистої гігієни виробниками і продав- цями. Для усунення ризику небезпек при виробництві ковбасних виробів необхідно застосовувати дієву систему контролю за якістю та безпечністю за системою НАССР $з$ використанням критичних точок ветеринарно-санітарного контролю від заготівлі сировини до переробки у м'ясопродукти, зберігання та реалізаціï. Варто звернути увагу фахівців ветеринарної медицини на те, що ветеринарно-санітарний контроль ковбас, які реалізуються в торгівельній мережі 
м. Житомира, не досконалий і сприяє допущенню в реалізацію ковбас, які не відповідають ветеринарносанітарним вимогам. Зокрема, ковбаса "Шинкова" та “Сардельки з сиром” ТОВ ВТФ “Мар'ян” не відповідають за санітарними показниками, а ковбаса "Шинкова" та "Молочна" ("М'ясна гільдія" ТОВ “Житомирський м'ясокомбінат”) - за фізико-хімічними (вміст солі та нітритів), тобто становлять небезпеку для здоров'я споживачів.

Одним із ефективних шляхів зменшення вмісту нітритів у раціоні споживача за рахунок м'ясопродуктів $\epsilon$ впровадження у виробництво безнітритної технології їх виготовлення, запропонованої Ковбасенко В. М., Горобеєм О. М. (2001), або заміна іншим безпечним барвником. Запропонований барвник - безпечний продукт, який надає стійкого кольору і дає змогу відмовитися від використання нітритів у ковбасному виробництві. Для його виготовлення запропонували використовувати кров, яку отримують при забої сільськогосподарсьських тварин. Кров стабілізують кухонною сіллю і обробляють $6 \%$ або $9 \%$ спиртовим розчином оцтової кислоти відповідно до запропонованої ним методики. Впровадження у виробництво безнітритної технології буде сприяти отриманню якісних і безпечних ковбасних виробів.

\section{Висновки}

1. За безпечністю ковбасні вироби, що реалізуються в торгівельній мережі м. Житомир, не завжди відповідають ветеринарно-санітарним вимогам. Ковбаса “Шинкова" та “Сардельки 3 сиром” ТОВ ВТФ "Мар'ян” не відповідали за санітарними показниками, ковбаса "Шинкова" та "Молочна" "М'ясна гільдія" ТОВ “Житомирський м'ясокомбінат" - за фізикохімічними (вміст солі та нітриту натрію перевищували нормативні вимоги), тобто становили небезпеку для здоров'я споживачів.

2. Санітарна якість та безпека м'ясопродуктів залежить від багатьох факторів: якості сировини, потужності м'ясопереробного підприємства, санітарного стану його обладнання та інвентаря, дотримання правил особистої гігієни працівниками при їх виготовленні та реалізації.

3. Для усунення ризику небезпек при виробництві ковбасних виробів необхідно застосовувати дієву систему контролю за якістю та безпечністю за системою НАССР з використанням критичних точок ветеринарно-санітарного контролю від заготівлі сировини до переробки у м'ясопродукти, зберігання та реалізацiï.

\section{References}

Bogatko, N., Bogatko, L., Salata, V., Semaniuk, V., Serdioucov, J., \& Schyrevuch, G. (2017). Veterinarysanitary control of safety and quality of meat products. Scientific Messenger of LNU of Veterinary Medicine and Biotechnologies. Series: Veterinary Sciences, 19(73), 7-10. doi: 10.15421/nvlvet7302.

Bogatko, N., Bukalova, N., Bogatko, L., Salata, V., ArtemenkoL., \& Poltavchenco, T. (2016). Control of quality of fish by use of an improved method for the determination of water-holding capacity of meat. Scientific Messenger of LNU of Veterinary Medicine and Biotechnologies. Series: Veterinary Sciences, 18(2(66), 8-12. doi: 10.15421/nvlvet6602.

Bohatko, N. M., Dzhmil, V. I., \& Marchenko, M. V. (2011). Veterynarno-sanitarna otsinka kovbasnykh vyrobiv za pokaznykamy yakosti ta bezpechnosti u TOV "Vizyt" m. Uzyn Kyivskoi oblasti. Visnyk Bilotserkiv. derzh. ahrar. un-tu, 87, 16-19 (in Ukrainian).

Bohatko, N. M., Salata, V. Z., \& Bohatko, D. L. (2013). Identyfikatsiia miasa tvaryn za pokaznykamy yakosti ta bezpechnosti. Nauk. visnyk Lviv. nats. universytetu vet. medytsyny ta biotekhnolohii im. S. Z. Gzhytskoho, 15(4), 8-12 (in Ukrainian).

Kasianchuk, V. V., Berhilevych, O. M., Yefimova, O. M., \& Rotasnko, Yu. (2015). Systema prostezhuvanosti suchasna tekhnolohiia kontroliu $\mathrm{V}$ kharchovomu lantsiuhu dlia pidvyshchennia rivnia bezpechnosti kharchovykh produktiv. Vet. medytsyna Ukrainy, 2, 25-29 (in Ukrainian).

Khitska, O. A., Bukalova, N. V. \& Slobodeniuk, O. I. (2008). Otsinka yakosti ta bezpeky m'iasa ta m'iasnykh produktiv v umovakh hipermarketu. Nauk. visnyk Lviv. nats. universytetu vet. medytsyny ta biotekhnolohii im. S. Z. Gzhytskoho, 10(1), 464-468 (in Ukrainian).

Kolesnyk, T. L., \& Kolesnyk, A. O. (2015). Biolohichna tsinnist varenykh kovbas, shcho mistiat barvnyk iz krovi. Prohresyvni tekhnika ta tekhnolohii kharchovykh vyrobnytstv restorannoho hospodarstva i torhivli: $\mathrm{zb}$. nauk. pr. Kharkiv: KhDUKhT, 1(21), 283-291. http://elib.hduht.edu.ua/handle/123456789/607 (in Ukrainian).

Kotelevich, V. (2017). Veterinary and sanitary assessment of food quality and safety in Zhytomyr region. Scientific Messenger of LNU of Veterinary Medicine and Biotechnologies. Series: Veterinary Sciences, 19(78), 58-61. doi: 10.15421/nvlvet7812.

Kotelevych, V. A., Zghozinska, O. A., \& Holovko, O. V. (2015). Vetsanekspertyza i vetsanotsinka kovbas TOV "Sumski miasni vyroby". Visnyk ZhNAEU, 1(3), 128-130 (in Ukrainian).

Kovbasenko, V. M., \& Horobei, O. M. (2001). Vyrobnytstvo kovbas bez vykorystannia nitrytiv i nitrativ. Ahrarnyi visnyk Prychornomoria, 4(14), 166169 (in Ukrainian).

Trokhymenko, V., Kalchuk, L., \& Didukh, M., Kovalchuk, T. I., \& Zakharin, V. V. (2018). Vykorystannia kharchovykh dobavok u kovbasnomu vyrobnytstvi ta yikh vplyv na orhanizm liudyny. Visn. Sumskoho nats. ahrar. un-tu. Ser. Tvarynnytstvo, 2(34), 233-237. http://nbuv.gov.ua/UJRN/ Vsna_tvar_2018_2_54 (in Ukrainian). 